\title{
Memahami Penderitaan Dalam 1 Petrus 4:12-19 Dan Implikasinya Dengan Situasi Pandemi Covid 19
}

\author{
Enjelia Marthen \\ Dicky Dominggus \\ Sekolah Tinggi Teologi Injil Bhakti Caraka Batam \\ Angelmarten28@gmail.com \\ Dicky.dominggus@sttibc.ac.id
}

\begin{abstract}
Abstrak
Penderitaan merupakan sesuatu yang menjadi bagian dalam kehidupan manusia. Artinya semua orang pasti mengalami penderitaan. Penderitaan yang dimaksud bisa dalam berbagai macam seperti sakit penyakit, kesusahan ekonomi, diskriminasi, tekanan psikologi dan lainnya. Petrus menuliskan penderitaan di dalam teks 1 Petrus 4:12-19. Di dalam teks ini, Petrus sedang mendorong jemaat agar bertahan dalam penderitaan yang dialami. Penelitian ini merupakan penelitian kualitatif dengan pendekatan historikal gramatikal. Dalam penelitian ini, dilakukan penelitian teks 1 Petrus 4:12-19 untuk menemukan makna mula-mula penderitaan yang dimaksudkan oleh Petrus. Berdasarkan penelitian yang dilakukan dapat disimpulkan bahwa penderitaan yang dimaksudkan oleh Petrus merupakan penderitaan karena iman kepada Kristus. Dengan demikian, penting bagi orang percaya pada masa kini untuk dapat memahami penderitaan dengan benar sebagai sesuatu yang wajar dihadapi manusia dan berada dalam kedaulatan Allah.
\end{abstract}

Kata Kunci: Penderitaan; 1 Petrus 4:12-19. 


\section{PENDAHULUAN}

Secara umum, topik mengenai penderitaan merupakan isu sepanjang zaman. Hal ini dikarenakan penderitaan adalah fakta yang tidak dikehendaki namun tidak dapat dihindari dan penderitaan sangat dekat dengan kehidupan manusia. Seorang tokoh yang bernama Darmaputera menulis dalam bukunya bahwa penderitaan merupakan bagian yang penuh dari kenyataan hidup (Pranoto, 2018). Untuk itu, penderitaan sudah menjadi bagian dalam kehidupan manusia yang hadir dalam bentuk yang berbeda-beda dan dirasakan berbeda oleh setiap manusia. Setiap orang tidak pernah kuat dalam menghadapi penderitaan, karena masalah yang dihadapi selalu bermunculan (Warren, 2005). Maksudnya adalah ketika masalah yang satu terselesaikan masalah yang lain sedang menanti dan semua orang menderita baik mental, emosi, fisik, maupun spirit.

Penderitaan selalu identik dengan kesusahan, ratapan, tangisan, karena penderitaan selalu dipandang negatif. Realitas penderitaan yang dialami oleh manusia pada dasarnya terjadi karena tindakan kejahatan yang didalamnya terdapat unsur ketidakadilan, penyakit, kecelakaan, kekerasan, pemerkosaan dan lain sebagainya (Kalis Stevanus dan Stefanus M Marbun, 2019). Namun tidak dapat dipungkiri bahwa penderitaan ialah fakta yang bersifat umum dan hal itu harus diterima oleh semua orang sebagai resiko hidup karena intensitas penderitaan yang dialami berbeda-beda, ada yang berat bahkan ada juga yang ringan.

Penderitaan merupakan hal yang tidak dapat dihindari dan dapat terjadi dalam beberapa bentuk. Ada yang mengalami penderitaan karena perekonomian atau kebutuhan, penyakit, kesusahan dan diskriminasi. dan lain sebagainya. Namun pada dasarnya, penderitaan merupakan keadaan yang sangat menyedihkan yang dirasakan karena tekanan, baik yang diakibatkan berbagai faktor yang ditanggungkan kepada individu maupun kelompok. Dengan demikian, penderitaan yang mengakibatkan keadaan seseorang menjadi lebih buruk dan tidak berdaya dalam menghadapi tantangan yang sedang dialaminya.

Pada tahun 2020, dunia menghadapi pandemic covid 19 yang berdampak pada banyak aspek. Beberapa aspek yang dimaksudkan 
adalah perekonomian dan bisnis menjadi lumpuh yang berdampak pada banyak perusahaan bangkrut dan karyawan dirumahkan, kegiatan pendidikan dan peribadatan terhenti dan diubah dengan metode online, kehidupan interaksi sosial manusia yang dibatasi dengan keadaan hidup baru yang disebut dengan new normal, hingga banyak orang yang meninggal akibat terkena virus covid 19. Dengan keadaan di atas, dapat dipastikan bahwa banyak orang yang menderita pada situasi pandemic covid 19.

Di dalam Alkitab ada banyak teks yang berbicara mengenai penderitan, salah satunya dalam kitab 1 Petrus 4:12-19. Secara umum, surat 1 Petrus banyak berbicara tentang penderitaan (Sara L Sapan dan Dicky Dominggus, 2020). Dalam tulisannya, Petrus menghimbau kepada orang percaya untuk siap sedia menderita dan rela merima perlakuan yang kejam dan tidak adil karena imannya. Tenney menuliskan bahwa Petrus sedang memberikan dorongan bagi jemaat yang menderita penganiayaan khususnya bagi gerejagereja yang ada di bagian utara Propinsi Asia kecil (Tenney, 2003).
Kondisi jemaat pada waktu itu sedang mengalami penganiayaan di bawah pemerintahan kaisar Nero.

Pada dasarnya, teks 1 Petrus 4:12-19 dituliskan Petrus dengan tujuan dorongan kepada orang percaya dalam menghadapi penderitaan. Eldon Ladd menuliskan melalui teks 1 Petrus 4:12-19, Petrus sedang memberikan bimbingan praktis kepada mereka yang mulai mengalami

penderitaan/penganiayaan sebagai umat Kristen dikalangan masyarakat kafir (Ladd, 2014). Bimbingan praktis yang dimaksudkan Ladd di sini lebih kepada dorongan untuk dapat bertahan di dalam penderitaan dan juga pengajaran bahwa penderitaan merupakan bagian dari kehidupan mengikut Yesus.

Jika dikaitkan dengan pembahasan sebelumnya, apakah makna mula-mula penderitaan dalam teks 1 Petrus 4:12-19 dan bagaimana bagaimana orang percaya pada masa kini terkait situasi pandemic covid 19? Penelitian ini bertujuan memahami makna penderitaan bagi orang percaya menurut 1 Petrus 4:1219 dan menemukan implikasinya pada penderitaan orang percaya pada 
masa kini terkait situasi pandemic covid 19.

\section{METODE PENELITIAN}

Penelitian ini merupakan kajian literatur teks Alkitab menurut 1 Petrus 4:12-19 yang berisi tentang penderitaan orang percaya. Metodologi penelitian yang digunakan adalah metodologi penelitian kualitatif, dengan menerapkan tipe metode historikal gramatikal. Historikal gramatikal merupakan metode yang berhubungan dengan tata bahasa dan bagian dari penafsiran Alkitab yang berguna untuk menemukan arti mulamula sebuah teks (Dominggus, 2020). Tujuan dari metode historikal gramatikal adalah memperoleh pemahaman yang lebih baik mengenai konteks yang memberikan makna (Dominggus, Makna Dosa Menghujat Roh Kudus, 2020). Pendekatan historikal gramatikal pada penelitian ini dengan mencari makna mula-mula dari teks 1 Petrus 4:12-19 tentang penderitaan orang percaya. Penelitian ini memiliki dua tahapan yaitu: Pertama, menemukan makna mula-mula penderitaan orang percaya dalam teks 1 Petrus 4:12-19. Kedua, menemukan implikasi bagi orang percaya pada masa kini terkait situasi pandemic covid 19.

\section{HASIL DAN PEMBAHASAN}

Analisa Teks 1 Petrus 4:12-19

Petrus menuliskan ayat 12 sebagai pendahuluan dari tulisannya kepada jemaat. Dalam ayat ini, Petrus menasihatkan agar orang percaya tidak heran dengan penderitaan yang sedang terjadi. Petrus mengawali tulisannya dengan frase "saudarasaudara yang terkasih" dalam bahasa Yunani 'A $\gamma \alpha \pi \eta \tau o$ berasal dari kata $\grave{\alpha} \gamma \alpha \pi \eta \tau o ́ \varsigma$ yang artinya yang dikasihi atau satu-satunya dikasihi. Saudarasaudara yang dimaksudkan Petrus disini adalah orang percaya yang sudah menjadi saudara di dalam Kristus. Dengan demikian maksud dari Petrus menuliskan frasa saudarasaudara terkasih sebagai tindakan pendekatan kepada orang percaya yang sedang mengalami penderitaan.

$$
\text { Pada bagian berikutnya, }
$$

Petrus menuliskan frase mengenai "nyala api siksaan". Petrus menggunakan frase ini dari bahasa

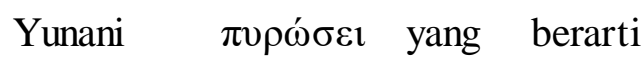
pembakaran, siksaan yang hebat, siksaan yang menyakitkan (Sutanto,

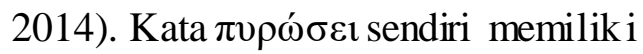
bentuk dativ feminim tunggal dari 
present participle yang menunjukkan hal itu sudah mulai, yang dipakai untuk Pelengkap, Penyerta yaitu orang yang kepadanya atau baginya dilakukan sesuatu (Wenham, 1987). Dengan demikian, frase nyala api siksaan yang dimaksudkan Petrus pada ayat ini adalah penderitaan yang lebih keras dari apa yang telah mereka alami selama ini.

Witness Lee melihat nyala api siksaan berarti menyala-nyala dan melambangkan tungku pemurni emas dan perak yang menyala-nyala (Lee, 1957). Maksudnya bahwa nyala api siksaan yang dimaksudkan Petrus dalam teks ini yaitu suatu penganiyaan bagi orang beriman yang diderita sebagai tungku perapian yang menyala-nyala. Dari pemaparan diatas, nyala api siksaan merupakan penderitaan atau kesengsaraan yang sangat besar yang dialami oleh orang percaya mula-mula yang ada diperantauan.

Penderitaan atau kesengsaraan yang dimaksudkan Petrus dalam teks ini yaitu sebagai ujian. Kata ujian dalam bahasa Yunani berarti $\pi \varepsilon \iota p \alpha \sigma \mu$ ò $\nu$ dari kata $\pi \varepsilon i \rho \alpha \sigma \mu$ ó $\varsigma$, yang artinya pencobaan (Sutanto, 2014). Paulus menuliskan kata ini untuk menjelaskan pencobaan dalam bentuk dosa yang diperhadapkan kepada jemaat. Untuk itu, dosa, kejahatan menjadi ujian atau cobaan bagi mereka. Namun, dapat diyakini bahwa Allah mengetahui bagaimana menyelamatkan orang percaya yang setia dari tengah-tengah umat yang tercemar karena dosa.

Pada ayat 13 Petrus menuliskan nasihat untuk bertahan dalam penderitaan. Kata bersukacitalah dalam bahasa Yunani

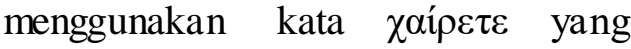
berasal dari kata $\chi \alpha i ́ p \omega$ yang artinya bersukacita, salam, memberi salam, hormat dan bersorak (Sutanto, 2014). Kata $\chi \alpha i ́ p \omega$ sendiri memiliki bentuk present imperaktif aktif orang ke-2 jamak. Petrus menggunakan kata ini sebagai pengingat bagi orang percaya untuk senantiasa melakukan nasehatnya. Untuk itu, teks ini menjelaskan bahwa dalam penganiyaan yang mereka alami, mereka harus bersukacita. Kata bersukacitalah merupakan kata kerja yang artinya bersuka hati atau bergirang hati. Selain itu, bersukacita juga dipahami sebagai kegirangan dan kata ini dipakai Petrus dalam teks 
tersebut. Jadi, bersukacita merupakan suatu sikap bahagia yang dilakukan dalam merespon suatu keadaan.

Fokus selanjutnya dalam teks ini yaitu frase "penderitaan Kristus" dalam bahasa Yunani yaitu $\pi \alpha \theta \eta \dot{\mu} \mu \sigma ı v$ dari kata $\pi \alpha ́ \theta \eta \mu \alpha$ yang artinya penderitaan; hawa nafsu (Sutanto, 2014). Kata $\pi \alpha \theta \eta \dot{\mu \alpha \sigma o v}$ menggunakan Dalam hal ini Paulus mencoba menjelaskan bahwa kehidupan Kristen mengambil bagian dalam penderitaan bersama dengan Kristus. Hal ini lebih di pertegas oleh Paulus dalam Rm.8:17 jika orang percaya menderita bersama dengan Kristus mengingatkan bahwa Yesus yang menderita dan kita yang mengikutinya juga akan menderita. Barclay menjelaskan bahwa ketika seseorang harus menderita karena kekristenannya, sesungguhnya ia sedang melalui jalan-jalan yang pernah dilalui Tuhannya dan turut memikul salib yang dipikul Tuhannya (Barclay, 1983).

Selanjutnya Petrus menuliskan frase "menyatakan kemuliaanNya". Maksud Petrus menggunakan frase ini untuk menjelaskan bahwa setiap orang percaya akan mendapatkan keindahan dari Allah yang tetap bertahan dalam penderitaan pada suatu waktu. Dalam hal ini Petrus menekankan pengharapan orang Kristen dalam menghadapi penderitaan. Orang Yahudi memiliki pemahaman mengenai Syekinah atau cahaya kemuliaan yang berasal dari Allah (Barclay, 1983).

Pada ayat 14 fokus utama pada bagian ini mengenai frase "jika kamu dinista dan Roh Kemulian”. Frase "jika kamu dinista," berasal dari

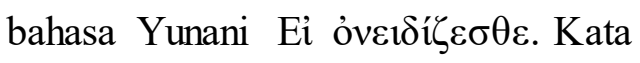
Eỉ disini menjelaskan kata penghubung, sedangkan kata

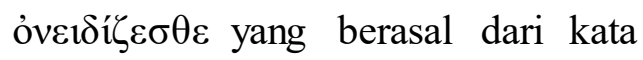

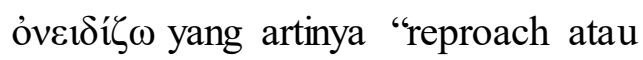
celaan.” Orang (Sutanto, 2014). Hal ini menjelaskan bahwa perintah itu ditujukan kepada orang banyak dan harus dilakukan secara terusmenerus. Jadi, ỏveı $\delta i ́ \zeta \varepsilon \sigma \theta \varepsilon$ yang dimaksudkan Petrus disini yaitu sesuatu yang berulang-ulang kali dilakukan yang ditujukan kepada orang banyak walaupun mengalami penolakan. Dalam teks ini menjelaskan bahwa orang percaya yang dinista karena nama Kristus harus berbahagia. Prinsipnya bahwa menderita karena Kristus merupakan suatu bentuk yang mampu 
memperdalam sukacita orang percaya dalam Tuhan.

Selanjutnya, frase mengenai kamu dinista diikuti dengan frase "Roh kemuliaan" menjadi fokus pada bagian ini. Roh kemulian berasal dari

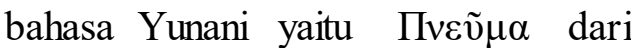
kata dasar $\pi v \varepsilon \tilde{u} \mu \alpha$, yang artinya napas, angin, sikap semangat. Kata Roh yang dimaksudkan Petrus dalam teks ini merujuk kepada kuasa yang akan menjadi bagian dalam hidup orang percaya. Hal ini dipertegas Rasul Petrus dengan maksud bahwa Roh Kemuliaan akan berdiam bagi orang percaya yang setia, yang akan memberi kuasa kemulian surga itu sendiri.

Selanjutnya pada ayat 15 ada beberapa kata yang akan menjadi fokus utama kata menderita. Kata menderita pada berasal dari bahasa Yunani yaitu $\pi \alpha \sigma \chi \varepsilon ́ \tau \omega$ dari kata dasar $\pi \alpha ́ \sigma \chi \omega$ yang artinya mengala mi, menderita (Sutanto, 2014). Dalam Bentuk dari kata $\pi \alpha \sigma \chi \varepsilon ́ \tau \omega$ dalam teks ini menggunakan present imperative aktiv orang ke-3 jamak, dimana bentuk kata kerja present imperative menjelaskan suatu perintah. Dengan demikian, kata $\pi \alpha \sigma \chi \varepsilon ́ \tau \omega$ yang dipakai Petrus dalam teks ini menjelaskan suatu perintah yang dilakukan oleh orang ke-2 atau orang ke-3.

Kata $\quad \pi \alpha \sigma \chi \varepsilon ́ \tau \omega \quad$ juga digunakan Paulus dalam Galatia 3:4. Dalam hal ini Paulus mengingatkan jemaat mula-mula mengenai Injil yang diberitakannya, karena orang percaya mula-mula dipengaruhi oleh guru-guru Yahudi dan memaksa mereka untuk disunat dan menerima kuk Taurat Musa (Henry, 2015). Dalam teks ini $\pi \alpha \sigma \chi \varepsilon \dot{\tau} \omega$ menurut tafsiran Waycliffe bahwa $\pi \alpha \sigma \chi \varepsilon \dot{\tau} \tau \omega$ yang dimaksudkan belum tentu adalah penganiayaan atau beban dalam mentaati hukum Taurat, karena diikuti dengan sebutan Roh dalam ayat selanjutnya (Charles F Pfeiffer dan Everett F Harrison, 2008). Tafsiran ini didukung oleh J.Gunning yang mengatakan bahwa pengalaman-pengalaman yang mereka alami bukan mengenai pengalaman yang payah (Penganiayaan) melainkan pengalaman yang indah (Gunning, 2001). Dari kedua pandangan ini menjelaskan bahwa $\pi \alpha \sigma \chi \varepsilon ́ \tau \omega$ yang dimaksudkan bukan suatu penganiayaan melainkan pengalaman-pengalaman yang pernah dialami oleh jemaat Galatia. 
Setelah Petrus melarang orang

Kristen untuk tidak menderita karena

kejahatan maka Petrus dalam ayat 16 meminta orang Kristen mula-mula untuk memuliakan Tuhan jika mereka menderita penganiayaan atas nama Kristus. Pada teks ini menjelaskan bahwa Petrus menasehati orang percaya mula-mula untuk fokus pada tujuan dalam penganiayaan yang mereka hadapi (Jonhston, 1963). Fokus pada frase ini, yaitu kata "hendaklah memuliakan dan merasa malu".

Kata "hendaklah memuliakan" dalam bahasa Yunani

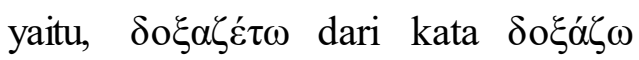
yang artinya, memuliakan, memuji, menghormati, memenuhi dengan mulia (Sutanto, 2014). Petrus dalam teks ini memberikan perintah kepada orang percaya sebagai suatu keharusan yang dilakukan.

Kata $\delta$ o $\xi \alpha ́ \zeta \omega$ juga muncul dalam Matius 5:16. Pada teks ini Yesus memakai perumpamaan sebagai gambaran dari keberadaan umatNya yang adalah terang dunia. Martin Harun menjelaskan bahwa kemuliaan yang dimaksudkan dalam teks ini merupakan Pujian bagi Allah sebagai anugerahNya melalui Yesus Kristus yang dicerminkan melalui perbuatan dan sikap yang kelihatan (Harun, 2016). Hal ini dipertegas oleh Sinclair B. Ferguson yang mengatakan bahwa perbuatan baik yang dilakukan oleh orang Kristen akan menjadi penghormatan kepada Allah (Ferguson, 2005). Disini menjelaskan bahwa melalui perbuatan baik yang dilakukan oleh orang parcaya menjadi salah satu cara memuliakan Allah.

Olehnya itu, Petrus mengingatkan mereka supaya ia jangan malu menderita karena Kristus. Yang menjadi pertanyaannya, Apakah maksud Petrus mengatakan jangan malu menderita kepada jemaat pada masa itu?. Merasa malu yang dimaksudkan Petrus dalam teks ini berasal dari bahasa Yunani $\alpha i \sigma \chi v v \varepsilon ́ \sigma \theta \omega$ dari kata dasar $\alpha i \sigma \chi v ́ v o \mu \alpha \iota$ yang berarti merasa malu; dipermalukan karena tidak mendapat apa yang diharapkan. Dalam hal ini menjelaskan bahwa orang percaya jangan menyembunyikan statusnya sebagai umat yang mengikut Kristus dihadapan dunia.

Pada bagian berikutnya, Petrus menuliskan kata penghakiman dan kesudahan. Kata penghakiman yang dijelaskan oleh Petrus dalam 
teks ini berasal dari bahasa Yuanani

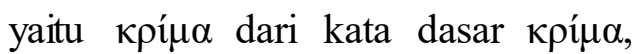
yang artinya perkara hukum, kuasa untuk menghakimi, vonis, keputusan, pemisahan (Sutanto, 2014). Ungkapan ini menjelaskan bahwa bumi yang sekarang belum mengalami hukuman, namun akan mengalami hukuman atau kebinasaan.

Selanjutnya, Petrus dalam ayat 17 mengatakan bahwa penghakiman atau hukuman itu dimulai dari rumah Allah. Rumah Allah yang dimaksudkan Pertus dalam kitab ini berasal dari bahasa Yunani ơ̌kov dari akar kata oĩkos yang berarti rumah: tempat tinggal istana, kota, keluarga, keturunan bangsa. Bentuk kata yang digunakan dalam teks ini menggunakan maskulin genetiv tunggal, karena kasus genetif dinyatakan oleh susunan kata (Wenham, 1987).

Dalam perjanjian lama Rumah Allah lebih merujuk kepada בית־יהוה (bait YHWH). Bait Allah dalam PL juga diartikan sebagai rumah, istana, penginapan בת tempat beribadah dari akar kata (beth). Walaupun istilah בת tidak hanya merujuk kepada Bait Allah hal ini juga merujuk kepada kuil dewadewi yang disebutkan dalam Kitab 1 Raj. 16:32. Dalam tradisi Israel rumah dijadikan tempat untuk mengajarkan Taurat kepada anggota keluarga bahkan orang Israel sangat mematuhi perintah Allah dengan serius (Philip J King dan L E Strager, 2012). Bukan hanya itu, rumah juga memiliki peranan sebagai tempat untuk beristarahat, berteduh, berlindung dan lain sebagainya (Kej. 19:8; Ul.6:4-9; Yer. 29:5). Dengan demikian, pemakaian kata rumah Allah bagi orang Israel sangat berkaitan erat dengan tempat yang dikhususkan untuk beribadah kepada Allah.

Untuk itu, O’̌kov yang dimaksudkan Petrus disini yaitu orang percaya yang setia, yang dipanggil dari gelap kepada terang yaitu Yesus Kristus dan merekalah yang lebih dulu mengalami penghakiman. Jadi, penghakiman itu dimulai dari Gereja Allah atau jemaat yang terdiri dari orang-orang yang percaya kepada Kristus, Petrus menjelaskan bahwa hukuman itu akan dimulai pada orang percaya tersebut. Selanjutnya, kata kesudahan yang dimaksudkan dalam teks ini 
yaitu $\tau \varepsilon ́ \lambda o \varsigma$ yang artinya kesimpulan, akhir atau tujuan. Kata $\tau \varepsilon ́ \lambda o \varsigma$ disebutkan sebanyak 40 kali dalam Perjanjian Baru. Bentuk dari kata ini yaitu neuter nominative tunggal. Maksud dari kesudahan dalam ayat ini yaitu hasil akhir yang akan di perloleh ketika hukuman itu tiba.

Kemudian,

Petrus

menjelaskan bahwa bagaimana dengan orang yang tidak percaya Injil?. Orang yang tidak percaya dalam bahasa Yunani yaitu

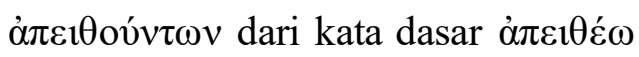
yang artinya tidak menaati/tidak percaya. (Sutanto, 2014) $\grave{\alpha} \pi \varepsilon \imath \theta$ ov́v$\tau \omega v$ dalam perjanjian baru disebutkan sebanyak 14 kali seperti dalam kitab Yohanes 3:36; Roma 2:8; Kisah para rasul 19:9; Ibrani 3:18 dan 1 Petrus 2:8 (Wenham, 1987). Dalam

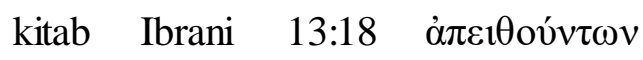
diterjemahkan sebagai orang-orang yang tidak taat, yang tidak mendapat tempat perhentian dalam Tuhan. Dalam hal ini menjelaskan bahwa janji Allah untuk umatNya berlaku.

Teks ini menjelaskan orang yang tidak taat seperti gambaran orang Israel yang tidak menaati janjijanji Allah yang mati di padang gurun dan tidak memasuki tanah perjanjian (Bil.13,14). Maksudnya bahwa mereka tidak taat dengan apa yang Allah tetapkan kepada mereka, mereka sangat mengabaikan kasih karunia, dan sumber jaminan untuk mereka sendiri. Untuk itu,

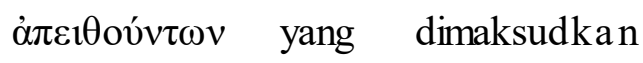
dalam Ibrani 13:8 menjelaskan orangorang yang tidak taat terhadap perintah Allah. Petrus menambahkan bahwa Tuhan mengizinkan penganiayaan sebagai penghakiman disiplin untuk memurnikan kehidupan keluarga dalam Tuhan.

Setelah itu, Petrus menggunakan frase "orang fasik"

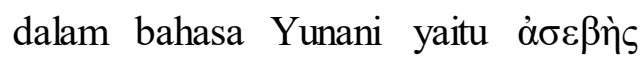
dari kata dasar $\dot{\alpha} \sigma \varepsilon \beta \eta ́ \varsigma$, yang artinya tidak saleh (Sutanto, 2014). Dalam teks lain seperti dalam 1 Tim.1:9

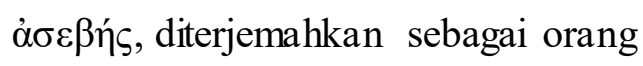
yang durhaka. Paulus dalam teks ini melanjutkan dengan menjelaskan apa yang dilakukan seseorang yang memperlakukan hukum taurat yang dianggap sebagai hukum Tuhan namun tidak dilakukan. Gordon D, Fee, dalam bukunya mengatakan bahwa konteks pada teks ini menjelaskan bahwa Taurat, bukan untuk orang benar, tapi untuk pelanggar hukum dan pemberontak, orang fasik dan orang berdosa (Fee, 1988). Menurut Fee, Paulus 
mengatakan bahwa hukum tidak ditujukan untuk "orang benar" namun bagi orang fasik, Fee juga menjelaskan bahwa Paulus merefleksikan poin yang dibuat sebelumnya di Galatia, bahwa mereka yang memiliki roh dan menghasilkan buahnya telah memasuki suatu lingkungan di mana hukum tidak lagi menjalankan fungsiny (Gal.5: 22-23) (Fee, 1988)

Pandangan Kelly juga menjelaskan bahwa Paulus dalam teks ini tidak meremehkan taurat, bahkan Paulus menjelaskan bahwa hukum itu diperlukan untuk menginsafkan akan dosa bagi yang tidak taat atau kepada $\alpha \sigma \varepsilon \beta \eta ́$ seperti yang dijelaskan dalam ayat 9-10 (Kelly, 1963). Maksudnya bahwa Paulus menarik perhatian, dan memberi pemahaman tentang itu untuk memungkinkan kita mengetahui apa yang dia maksud ketika Paulus mengatakan bahwa Hukum itu baik jika kita menggunakannya dengan cara yang

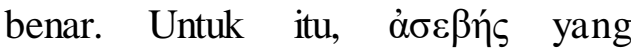
dijelaskan dalam 1 Tim.9 juga merujuk kepada orang durhaka yang tidak menaati Allah.
Bukan hanya orang fasik atau orang-orang yang tidak taat, yang dimaksudkan oleh Petrus namun juga orang berdosa. Jadi, orang berdosa yang dimaksudnya berasal dari bahasa Yunani yaitu $\dot{\alpha} \mu \alpha \rho \tau \omega \lambda$ ò dari $^{2}$ kata $\quad \dot{\alpha} \mu \alpha \rho \tau \omega \lambda$ ós,yang artinya berdosa, berbuat kesalahan (Sutanto, 2014). Kata $\quad \dot{\alpha} \mu \alpha \rho \tau \omega \lambda \operatorname{có}_{\text {, }} \quad$ juga digunakan Paulus semasa ia dihadapan Festus ketika Paulus naik banding kepada Kaisar (Kis. 25:8). $\dot{\alpha} \mu \alpha \rho \tau \omega \lambda$ ós, dalam kisah para rasul 25:8 Alkitab terjemahan baru, diterjemahkan "berbuat salah." Walaupun, dosa dan kesalahan itu memiliki perbedaan. Untuk itu, kesalahan seseorang bisa diperbaiki, namun dosa seseorang tidak bisa diperbaiki oleh diri sendiri kecuali Allah. Olehnya itu, $\dot{\alpha} \mu \alpha \rho \tau \omega \lambda$ ós, yang dimaksudkan Petrus adalah mereka yang berbuat salah kepada Allah yang menjelaskan bahwa kesalahan itu sangat fatal yang setara dengan dosa yang dilakukan oleh manusia.

Selanjutnya, pada ayat 19 yang menjadi fokus dalam bagian ini yaitu "menderita karena kehendak Allah, menyerahkan jiwanya, dan Pencipta yang setia." Frasa menderita karena kehendak Allah dalam teks ini 


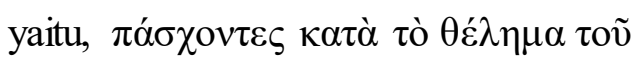

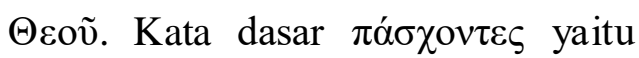
$\pi \alpha ́ \sigma \chi \omega$ yang artinya mengalami penderitaan yang diikuti kata $\kappa \alpha \tau \grave{\alpha}$ yang dijelaskan sebagai kalimat penghubung (Sutanto, 2014). Hal ini menjelaskan bahwa orang percaya menderita karena kehendak Allah. Kata "Kehendak" dalam bahasa Yunani yaitu $\theta \varepsilon \dot{\lambda} \lambda \mu \alpha$ yang artinya kehendak atau keinginan, Dag Herward Mill menguraikan kehendak Allah menjadi dua bagian yaitu, kehendaka Allah yang sempurna merujuk kepada Roma 12:2 dan kehendak Allah yang tidak sempurna (Mills, 2015). Dag Henward mengemukakan bahwa kehendak Allah yang sempurna yaitu kehendak yang utuh dan lengkap untuk dilakukan. Sedangkan kehendak Allah yang tidak sempurna adalah apa yang Tuhan biarkan untuk dilakukan umatNya walaupun hal ini bukan menjadi pilihan pertama Allah bagi mereka (Mills, 2015). Kehendak Allah yang dimaksudkan Petrus dalam ayat ini yaitu perintah yang Allah inginkan pada umatNya untuk dilakukan.

Untuk itulah Petrus terus mengingatkan orang percaya untuk selalu melakukan kebaikan walaupun mengalami penganiayaan sesuai dengan keinginan Tuhan dan orang Kristen harus tetap menyerahkan hidupnya kepada Allah sang Pencipta. Kata $\pi \alpha \rho \alpha \tau \theta \varepsilon \dot{\varepsilon} \sigma \theta \omega \sigma \alpha v$ juga digunakan Tuhan Yesus dalam Luk.23:46, sebagai kata kerja eksepneusen (untuk menghembuskan napas terakhirNya) yang dikutip dari Maz 31:6 (Guthrie, 1974). Hal ini menjelaskan bahwa Yesus rela menyerahkan nyawanya dengan penuh kesadaran kepada Bapa melalui kematian (Nielsen, 2009). Yohanes 19:30 juga menjelaskan bahwa Yesus menyerahkan nyawanya (paradokhen to pneuma) dengan sadar sepenuhnya dan sukarela (Charles F Pfeiffer dan Everett F Harrison, 2008). Jadi, Petrus pada teks ini menghimbau orang percaya pada masa itu, untuk menyerahkan nyawanya atau jiwanya kepada sang Pencipta dengan penuh kerelaan dan kesadaran total.

Untuk itu, Pencipta yang setia yang dimaksud pada ayat ini dalam

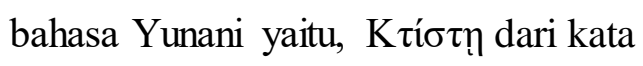
dasar $\pi \iota \tau \tau \tilde{\omega}$ yang artinya Pencipta. Pencipta yang dimaksudkan Petrus, merupakan Allah yang mahakuasa yang mampu membuat segala sesuatu dengan tangan yang kosong. Olehnya 
itu, Petrus terus mengajak jemaat pada saat itu untuk selalu berbuat baik dan menyerahkan hidupnya kepada Allah yang Mahakuasa.

Berdasarkan analisa teks 1

Petrus 4:12-19 dapat disimpulkan bahwa penderitaan orang Kristen dalam konteks kitab 1 Petrus 4:12-19 merupakan penganiayaan atau siksaan yang sangat kejam yang dialami sebagai cobaan untuk memurnikan iman. Penderitaan itu, tidak selamaya dialami atau ada dalam kehidupan orang percaya. Oleh karena itu, Petrus mengajak orang percaya untuk tetap bersukacita dan bergembira sebab mereka mengambil bagian dalam penderiaan Kristus secara jasmani. Petrus juga menegaskan bahwa setiap orang yang bertahan dalam pencobaan itu, akan mendapat sukacita yang lebih besar pada waktu Allah menyatakan kemuliaanNya.

$$
\text { Dalam penderitaan, orang }
$$
beriman perlu menyadari bahwa Allah berdaulat atas segala sesuatu, yang menjelaskan bahwa tidak ada sesuatu yang terjadi diluar kehendak Allah, juga segala sesuatu tidak kebetulan namun semuanya dalam rencana Allah (Stevanus, 2019).
Untuk itu, ketika orang percaya mengalami penderitaan maka perlu melakukan perenungan kepada Allah sehingga tidak mengalami keputusasaan ketika dalam keadaan menderita.

Sebagai umat yang percaya juga perlu menyadari bahwa penderitaan adalah keadaan yang bukan lagi sesuatu yang mengagetkan, karena orang percaya pada prinsipnya menderita sebagai salib yang harus dipikul. Seorang Teolog yang bernama Kazoh Kitamori mengatakan bahwa hakekat Allah adalah penderitaan. Untuk itu, penderitaan harus dipahami dengan benar mengenai maksud dan tujuannya dalam hidup orang Kristen.

\section{Implikasi Dengan Situasi Pandemi} Covid 19

Konteks Penderitaan dalam teks 1 Petrus dengan penderitaan pada masa pandemic covid 19 merupakan dua hal yang berbeda. Di dalam 1 Petrus, penderitaan lebih dilihat kepada sesuatu yang terjadi karena iman kepada Kristus. Karena itu, Petrus menuliskan agar orang percaya dapat bertahan di dalam penderitaan yang terjadi. Hal berbeda dengan 
penderitaan pada situasi covid 19 merupakan penderitaan yang terjadi karena kelalaian manusia.

Meski dalam konteks yang berbeda, benang merah yang dapat diambil adalah bagaimana respon orang percaya dalam menyikapi penderitaan? Dewantara menuliskan pada dasarnya setiap manusia pasti menderita,tetapi iman yang membuat manusia beriman memiliki memiliki sudut pandang lain dalam menyikapinya (Dewantara, 2020). Pendapat dewantara mneunjukkan bahwa penderitaan dapat dimaknai berbeda ketika seseorang memiliki iman kepada Allah. Artinya, Allah berkuasa penuh atas kehidupan seseorang dan termasuk penderitaan berada dalam kedaulatan-Nya. Sonny Zaluchu menuliskan bahwa penderitaan merupakan representative kedaulatan Allah (Zaluchu, 2017).

Penderitaan dapat dipahami juga sebagai hal yang wajar. Hal ini disebabkan oleh penderitaan merupakan bagian dari kehidupan manusia. Artinya, tidak ada seorangpun yang dapat terhindar dari penderitaan. Untuk itu, manusia perlu memahami konsep yang benar tentang penderitaan. Kalis Stevanus menuliskan bahwa penderitaan harus dipahami sebagai bagian integrai dari kehidupan manusia (Kalis Stevanus dan Stefanus M Marbun, 2019).

Penderitaan juga merupakan harga yang harus dibayar oleh orang percaya. Artinya, penderitaan sebagai sesuatu yang wajar di dalam kehidupan orang percaya. Yesus mengatakan barang siapa yang mengikuti-Nya harus menyangkal diri dan memikul salib. Warseto Sihombing menuliskan penting bagi orang percaya untuk memahami penderitaan sebagai kehendak Allah dan bertujuan membuktikan kemurnian iman di dalam Kristus (Sihombing, 2019).

\section{SIMPULAN}

\section{DAN}

\section{REKOMENDASI}

Penderitaan merupakan hal yang tidak dapat dihindari dalam kehidupan manusia. Penderitaan merupakan bagian dari kehidupan manusia. Faktanya, penderitaan dapat berupa macam bentuk seperti masalah ekonomi, kesehatan, diskriminasi, hingga berbagai kesusahan lainnya. Petrus menuliskan teks 1 Petrus 4:12-19 untuk mendorong jemaat agat bertahan dalam penderitaan yang mereka 
alami. Artinya, Petrus sedang menyadarkan bahwa penderitaan yang mereka hadapi sebagai orang percaya merupakan hal yang wajar sebagai harga yang harus dibayar dalam mengikuti Yesus. Untuk itu, orang percaya harus dapat memaknai penderitaan dengan benar. Dalam kaitannya dengan situasi pandemic covid, orang percaya diharapkan lebih kepada mempercayai sebagai pribadi yang berdaulat atas penderitaan. Dengan demikian, setiap orang percaya dapat bertahan di dalam pernderitaan yang terjadi.

\section{DAFTAR PUSTAKA}

Barclay, W. (1983). William Barclay, Pemahaman Alkitab Setiap Hari: Surat Yakobus, 1 dan 2 Petrus. Jakarta: BPK Gunung Mulia.

Charles F Pfeiffer dan Everett F Harrison. (2008). The Wyclife Bible Commentary. Malang: Gandum Mas.

Dewantara, A. W. (2020). Manusia Beragama Memahami Penderitaan. JPAK: Jurnal Pendidikan Agama Katolik, 14-25.

Dominggus, D. (2020). Keuddukan Kristus Dalam Penciptaan Menurut Kolose 1:15-20. Religi: Jurnal Studi Agamaagama, 42-63.
Dominggus, D. (2020). Makna Dosa Menghujat Roh Kudus. Veritas Lux Mea: Jurnal Teologi dan Pendidikan Kristen, 71-79.

Fee, G. D. (1988). New International Biblical Commentary: 1 and 2 Thimoty, Titus. Peabody: Hendrikson Publisher.

Ferguson, S. B. (2005). Kotbah di Bukit. Surabaya: Momentum.

Gunning, J. J. (2001). Tafsiran Alkitab: Surat Galatia. Jakarta: BPK Gunung Mulia.

Guthrie, D. (1974). Tafsiran Alkitab Masa kini Vol 3: MatiusWahyu. Jakarta: Yayasan Bina Kasih .

Harun, M. (2016). Matius: Injil Segala Bangsa. Yogyakarta: Kanisius.

Henry, M. (2015). Surat Galatia, Efesus, Filipi, Kolose, 1 dan 2 Tesalonika, 1 dan 2 Timotius, Titus dan Filemon. Surabaya: Momentum.

Jonhston, W. B. (1963). Calvin's Commentaries: The Epistle of Paul Then Apostle to the Hebrews and The First and Second Epistles of st Peter. Edinburg: The Saint Anderw Press.

Kalis Stevanus dan Stefanus M Marbun. (2019). Memaknai Kisah Ayub Sebagai Refleksi Iman Dalam Menghadapi Penderitaan. Logia: Jurnal Teologi Pentakosta, 25-43.

Kelly, B. H. (1963). The Layman's Bible Commentary: 1 and 2 Thessalonians, 1 and 2 Thimoty, Titus, Philemon. 
DIEGESIS: Jurnal Teologi

Volume 6 No. 1, Februari 2021 Hlm 20-35

Louiseville: John Knox Press.

Ladd, G. E. (2014). A Theology of The New Testament. Bandung: Yayasan Kalam Hidup.

Lee, W. (1957). Pelajaran Hayat Markus. Surabaya: Yayasan Perpustakaan Injil.

Mills, D. H. (2015). Seni Mendengarkan: Bagaimana Berada Dalam Kehendak Allah Yang Sempurna. Indonesia: Rumah Perkamen.

Nielsen, J. T. (2009). Tafsiran Alkitab: Kitab Injil Matius 2328. Jakarta: BPK Gunung Mulia.

Philip J King dan L E Strager. (2012). Kehidupan Orang Israel Alkitabiah. Jakarta: BPK Gunung Mulia.

Pranoto, D. S. (2018). Tinjauan Teologis Konsep Bangsa Israel Tentang Kematian. Bengkulu: Lingkar Barat.

Sara L Sapan dan Dicky Dominggus. (2020). Tanggung Jawab Penggembalaan Berdasarkan Perspektif 1 Petrus 5:1-4. Jurnal Teologi Amreta, 124145.

Sihombing, W. F. (2019). Penderitaan Orang Percaya Dalam Surat 1 Petrus. Kerugma: Jurnal Teologi dan Pendidikan Agama Kristen, 142-151.

Stevanus, K. (2019). Kesadaran Akan Alah Melalui Penderitaan Berdasarkan Ayub 1-2. Dunamis: Jurnal Teologi dan Pendidikan Kristiani, 111134.

Sutanto, H. (2014). Perjanjian Baru Interlinear Yunani-Indonesia dan Konkordansi Perjanjian baru (PBIK) Jilid 2. Jakarta: Lembaga Alkitab Indonesia.

Tenney, M. C. (2003). Survei Perjanjian Baru. Malang: Gandum Mas.

Warren, R. (2005). The Purpose Driven Life. Malang: Gandum Mas.

Wenham, J. W. (1987). Bahasa Yunani Koine. Malang: SAAT.

Zaluchu, S. E. (2017). Penderitaan Kristus Sebagai Wujud Solidaritas Allah Kepada Manusia. Dunamis: Jurnal Teologi dan Pendidikan Agama Kristen, 61-74. 